Int. J. Electrochem. Sci., 11 (2016) 10123 - 10134

International Journal of

ELECTROCHEMICAL

SCIENCE

www.electrochemsci.org

\title{
Conducting Polymer All Solid State Potentiometric Sensor for the Tramadol Assay
}

Farnoush Faridbod", Atefeh Shafaat, Mohammad Reza Ganjali

Center of Excellence in Electrochemistry, School of Chemistry, College of Science, University of Tehran, Tehran, Iran

*E-mail: faridbodf@khayam.ut.ac.ir

doi: $10.20964 / 2016.12 .37$

Received: 31 August 2016 / Accepted: 1 October 2016 / Published: 10 November 2016

A new methodology was applied for the designing potentiometric membrane sensors. An electrochemically polymerized Poly(Pyrrole)s (PPy) film was applied as a solid contact-ion to electron transducer on the surface of a pencil graphite electrode (PGE) to make an all-solid-state ion selective electrode (CP-ASS-ISE) for the determination of Tramadol Hydrochloride. A thin layer of a PVC membrane containing synthesized ion-pair as the active element and suitable plasticizer was then placed on the surface of the conducting polymer layer to prepare the sensor. The suggested sensor showed a Nernstian response (a slope of $57.17 \mathrm{mV}$ per decade) over the concentration range of $1.0 \times 10^{-6}$ to $1.0 \times 10^{-1} \mathrm{~mol} \mathrm{~L}^{-1}$. The Tramadol sensor had a low detection limit of $7.4 \times 10^{-7} \mathrm{~mol} \mathrm{~L}^{-1}$ with response time of less than $10 \mathrm{~s}$ in the concentrated solutions. The working $\mathrm{pH}$ range of the sensor was 2.0-7.0. Finally, the proposed sensor used for the Tramadol assay in some pharmaceutical tablets.

Keywords: Potentiometry; Tramadol hydrochloride; Conducting Polymer; All-solid-state ion selective electrode (ISE); Poly(Pyrrole)s

\section{$\underline{\text { FULL TEXT }}$}

(C) 2016 The Authors. Published by ESG (www.electrochemsci.org). This article is an open access article distributed under the terms and conditions of the Creative Commons Attribution license (http://creativecommons.org/licenses/by/4.0/). 